\title{
PERFORMANCE OF NON WOVEN SYNTHETIC FABRIC AND DISC FILTERS FOR FERTIRRIGATION WATER TREATMENT
}

\author{
Túlio Assunção Pires Ribeiro ${ }^{1}$; José Euclides Stipp Paterniani2*; Rogério Pereira da Silva \\ Airoldi²; Marcelo Jacomini Moreira da Silva ${ }^{2}$ \\ ${ }^{1}$ UNICAMP/FEAGRI - Depto. de Água e Solo na Área de Qualidade da Água para Irrigação - C.P. 6011 - \\ 13083-875 - Campinas, SP - Brasil. \\ 2UNICAMP/FEAGRI - Depto. de Água e Solo. \\ *Corresponding author 〈pater@agr.unicamp.br>
}

\begin{abstract}
Obstruction of emitters caused by the presence of solid particles in the water raises the cost and maintenance of trickle irrigation systems, and might compromise their utilization. This research was performed through test fields, with the objective of evaluating the performance of a disc filter (130 microns) and a non woven synthetic fabric filter on the removal of physical, chemical and biological impurities from the irrigation water, which may cause emitter obstruction during fertirrigation processes. The evaluation criteria of the impurities present in the irrigation water, were based on studies performed on trickle irrigation systems. Specifically, physical, chemical and biological parameters analyzed in the inflow and outflow water from both filters were: $\mathrm{pH}$, turbidity, total suspended solids, salinity, total iron, sulphites, manganese, algae and bacteria. Results pointed to chemical factors, which presented medium clogging risks to the emitters; those factors were: $\mathrm{pH}$, total iron and sulphite concentration. All the other parameters of water quality did not present clogging risks. A comparative analysis of head loss evolution, according to the filtered volume, was also atempted Non woven synthetic fabric filter presented a higher evolution when compared to the disc filter.
\end{abstract}

Key words: dripper, filtration, water quality, irrigation

\section{DESEMPENHO DOS FILTROS DE MANTAS NÃO TECIDAS E DE DISCO NO TRATAMENTO DE ÁGUA PARA FERTIRRIGAÇÃO}

\begin{abstract}
RESUMO: Um dos fatores que elevam os custos de operação e manutenção dos sistemas de irrigação localizada e, em certos casos, inviabiliza a utilização desse método, é a obstrução de emissores pela presença de partículas sólidas na água de irrigação. O presente trabalho teve por objetivo principal estimar, através de ensaios experimentais de campo, o desempenho de um filtro de disco (130 microns) com outro de manta sintética não tecida na remoção de impurezas de origens físicas, químicas e biológicas presentes na água de irrigação que promovem o entupimento dos emissores, quando se utiliza a fertirrigação. Os critérios para avaliação das impurezas presentes na água de irrigação foram baseados nos estudos realizados em sistemas de irrigação localizada. Especificamente foram analisados os seguintes parâmetros físico-químicos e biológicos da água afluente e efluente dos filtros: $\mathrm{pH}$, turbidez, sólidos suspensos totais, salinidade, ferro total, sulfetos, manganês, algas e bactérias. Os fatores químicos que apresentaram médio risco de obstrução aos emissores foram $\mathrm{pH}$, concentração de ferro total e sulfetos. Todos os demais parâmetros de qualidade de água analisados resultaram em valores que não apresentam risco de entupimento aos gotejadores. Procurou-se também fazer o acompanhamento da evolução da perda de carga em função do volume filtrado para os filtros, para realizar uma análise comparativa. No filtro de manta sintética não tecida, a evolução da perda de carga foi mais acentuada e mais rápida em relação ao de disco, por causa da sua maior eficiência na remoção de algas e bactérias.

Palavras-chave: gotejamento, filtragem, qualidade de água, irrigação
\end{abstract}

\section{INTRODUCTION}

Emitter obstruction and filter system clogging, may be caused by three main facts: suspended organic and inorganic material; chemical constitution and presence of bacteria (Nakayama et al., 1977). Regarding algae growth in the sources from where water is collected and also their growth inside the irrigation pipes, it can be observed that algae formation is even worse for fertirrigation, which is the most used technique in trickle irrigation.

Filtering mechanisms can be divided in two categories: screen and disc filters and grainy or sand filters. 
The first are classified as mechanic or surface filtering elements, in which the filtering process is based on the principle that the filtering pores are smaller than the diameter of particles to be filtered. In grainy or sand filters, particles to be held are smaller than the pores present in the filtering element; however, the retaining is made through physical-chemical processes (Adin \& Alon, 1986). Few experiments have characterized the remotion capacity of the surface filtering, while current experiments demonstrate the possibility of using the non-woven, synthetic fabric filter as a more efficient filtering element for the removal of suspended solids from trickle irrigation systems (Paterniani \& Silva, 1996). The combination of porosity characteristics, especific surface and thickness of the non-woven, synthetic fabric filters, as well the filtration index, water quality and filtering systems that are used, are all parameters that determine the non-woven, synthetic fabric filter adecquacy to the filtering condition (Paterniani, 1991).

Silva (1996) accomplished many laboratory tests, simulating water contamination by suspended solids, using sand at concentration 70 to $300 \mathrm{mg} \mathrm{L}^{-1}$. It was observed that non-woven, synthetic fabric filters removed $15 \%$ to $25 \%$ of the suspended solids; meanwhile, screen filter removed $2 \%$ and disc elements, with 130 microns, removed $10 \%$. This difference in the removal of suspended solids, using disc and screen filters, is attributed to the filtering elements which are different in structure, when compared to the non-woven, synthetic fabric filters.

The disc filtering element is composed by a set of rings with grooves printed on a central support, which is cylindric and perforated. The water is filtered when passing through the conductors, formed by the grooves placed between the consecutive rings. The screen filter element is constituted by a device, usually cylindric, that holds in its interior the filtering element, composed by a plastic or metallic support covered by a screen (Lopez et al., 1992). The difference between disc or screen filters and non-woven, synthetic fabric filtering elements are hydraulic conductivity, specific surface, effective filtering area and the synthetic woven thickness; itens which lead non-woven, synthetic fabric filters to a better filtering adaptation.

Scatolini (2001) has compared the filtering efficacy between screen and disc filtering elements, with 130 microns, and non-woven, synthetic fabric filters. The author concluded that non-woven, synthetic fabric filters were much more efficient than disc and screen filters in the removal of suspended solids and algae present in the irrigation water.

In the current research, through field essays, the performance of two filters was evaluated regarding to the removal of chemical, physical and biological impurities from irrigation water. One was the disc filter (130 microns) and the other a non-woven, synthetic fabric filter.

\section{MATERIAL AND METHODS}

The evaluation criteria for impurities present in the irrigation water were based on studies developed by Bucks \& Nakayama (1986). It has also been attempted to run a comparative analysis on the evolution of head loss, in relation to the filtered volume between the two filters.

The water used in the experiment came from a 250- $\mathrm{m}^{3}$ local, dammed-creek reservatory, in Campinas, SP, Brazil. The irrigation system was composed by a centrifuge-motor pump, an automatic irrigation controller, two solenoid electric valves, drippers, a datalogger, two pressure differential transducters, two pressure regulators, three digital turbine-type hydrometers (flow average of $0.6-6 \mathrm{~m}^{3} \mathrm{~h}^{-1}$ ), two manometers, one-piston, a fertilizer injection system (dosing pump), a filtering system of 130 microns and $25.4 \mathrm{~mm}$ disc filter and a non-woven, synthetic fabric filter (Figure 1).

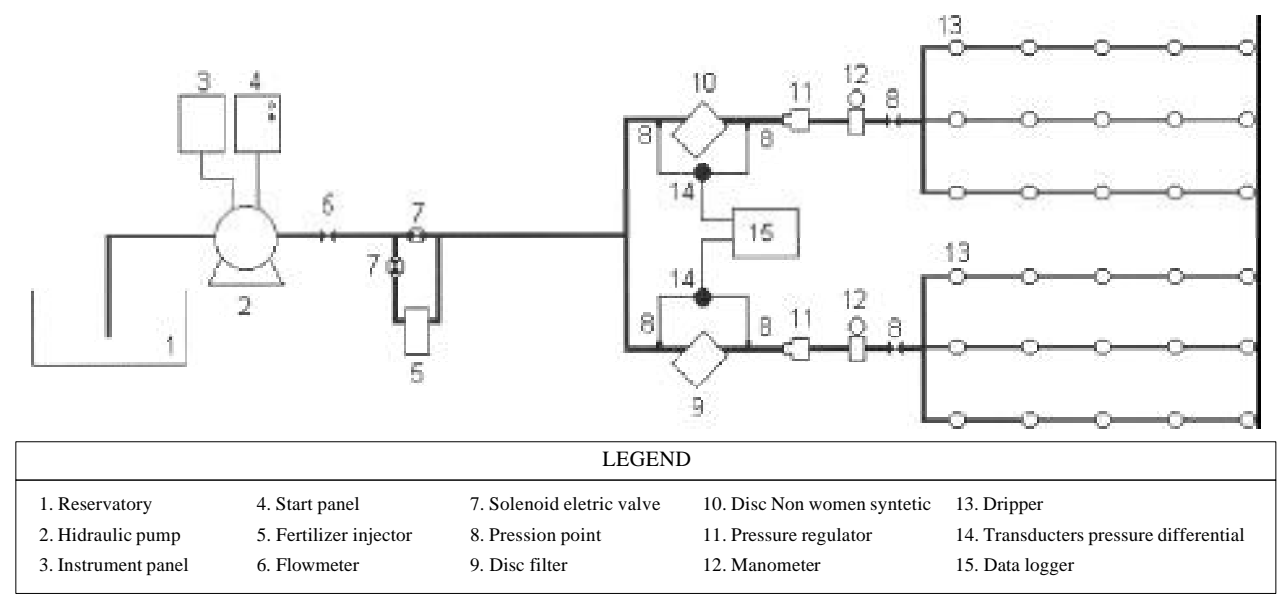

Figure 1 - Schematic presentation of the trickle irrigation system.

Sci. Agric. (Piracicaba, Braz.), v.61, n.2, p.127-133, Mar./Apr. 2004 
Organic-mineral fertilizers were used to perform the fertirrigation, presented in liquid form of density 1,270 $\mathrm{kg} \mathrm{m}^{-3}$. Its composition according to the original manufacturer is: $25 \%$ organic material, $3 \%$ total nitrogen and $9 \%$ potassium as $\mathrm{K}_{2} \mathrm{O}$. Few conservation problems were found by the time it was mixed in water. This solution is used for vegetables in general, flowers and fruits and seed greenhouses.

The two filters diferred only regarding filtering element, guaranteing functional similarity. The choice of the non-woven, synthetic fabric filter was made according Scatolini (2001). The non-woven, synthetic fabric used as filtering beand has $0.5 \mathrm{~cm} \mathrm{~s}^{-1}$ permeability, $1.6 \mathrm{~s}^{-1}$ permissivity, $0.150 \mathrm{~mm}$ pore openings, $380 \mathrm{~g} \mathrm{~m}^{-2}$ gramature, and $3.8 \mathrm{~mm}$ thickness.

Analyses of irrigation - constituting of algae concentration, bacteria, suspended solids and turbidity - water samples were performed before and after the utilization of the two filters, according to the methodologies presented in "Standard Methods for the Examination of Water and Wastewater" (AWWA; APHA; WPCF; 1995). The analyses were performed twice a week, in a total of 10 samples (Table 2). These data were used to determine the most important physical, chemical and biological factors related to water quality for trickle irrigation, that may cause the dripper obstruction (Bucks \& Nakayama, 1986) and also the factors that cause the turbidity, algae concentration, hardness and the Langelier Index.
The Langelier Index, a measure of the $\mathrm{CaCO}_{3}$ precipitation tendency, present in the irrigation water, was estimated because it is related to the $\mathrm{pH}, \mathrm{HCO}_{3}^{-}, \mathrm{Ca}^{+2}$ and the total salt concentration in the water (Nakayama \& Bucks, 1985). Positive values, indicate a precipitation tendency of $\mathrm{CaCO}_{3}$, causing the dripper cloggings; negative values maintain the $\mathrm{CaCO}_{3}$ in solution (Ayres \& Westcot, 1991).

Monitoring of pressure head loss in the filters was performed by transducters of pressure differential, before and after filtering. Data were stored in a datalogger, reading head losses every six seconds. After 30 days of essay, data were gathered in a report, and medium values were taken for localized head losses for every 10 minutes of irrigation. Each filter operated with an outflow of $0.6 \mathrm{~m}^{3} \mathrm{~h}^{-1}$, within two 2-hours watering shifts, providing a sum of 72.0 $\mathrm{m}^{3}$ for filtered water, for each filtering element. The increase of head loss resulting from impurity retention by the filters was evaluated according to the filtered volume.

\section{RESULTS AND DISCUSSION}

The quality of the reservatory water one day average can be seen in Table 1. The main sampling point was located in the main irrigation line, after the pumping system and before the fertilizer injector system. Results qualify the water that was used for irrigation during the period, indicating also the obstruction risks offered to the drippers.

Table 1 - Physical, chemical and biological characteristics of the irrigation water within the period from June $29^{\text {th }}$ to July $30^{\text {th }}$ 2001.

\begin{tabular}{|c|c|c|c|c|c|c|c|c|c|c|c|}
\hline \multirow{3}{*}{$\begin{array}{l}\text { Number of essay } \\
\text { and date }\end{array}$} & \multicolumn{11}{|c|}{ Parameters of the Irrigation Water } \\
\hline & \multicolumn{2}{|c|}{ Physical } & \multicolumn{7}{|c|}{ Chemical } & \multicolumn{2}{|c|}{ Biological } \\
\hline & $\begin{array}{l}\text { Suspended } \\
\text { solids }\end{array}$ & $\begin{array}{c}\text { Turb. } \\
\text { (NTU) }\end{array}$ & $\mathrm{Ph}$ & Iron & Sulphite & $\begin{array}{c}\text { Electrical } \\
\text { Cond. }\end{array}$ & $\begin{array}{c}\text { Dissolved } \\
\text { Solids } \\
\end{array}$ & Hardness & $\begin{array}{c}\text { Langelie } \\
\text { Índex }\end{array}$ & Algae & Bacteria \\
\hline & $\mathrm{mg} \mathrm{L}^{-1}$ & & & $---m$ & $\mathrm{~g} \mathrm{~L}^{-1}-\cdots$ & $\mathrm{mS} \mathrm{cm} \mathrm{cm}^{-1}$ & $------m g$ & $\mathrm{~L}^{-1}-\cdots-{ }^{-}$ & & $--n^{\circ}$ & $\mathrm{cm}^{-3}---$ \\
\hline $1-(06 / 29 / 01)$ & 5.0 & 3.88 & 7.1 & 1.0 & 1.0 & 0.056 & 35.84 & 26.63 & -2.077 & 165 & 600 \\
\hline $2-(07 / 02 / 01)$ & - & 2.69 & 7.3 & 0.5 & 1.0 & 0.076 & 48.64 & 25.72 & -1.399 & 255 & 1000 \\
\hline 3- $(07 / 05 / 01)$ & - & 3.51 & 7.7 & 0.5 & 1.0 & 0.056 & 35.84 & 22.96 & -1.6 & 1295 & 6500 \\
\hline $4-(07 / 10 / 01)$ & - & 2.2 & 7.2 & 0.5 & 1.0 & 0.067 & 42.88 & 22.04 & -2.173 & 480 & 6500 \\
\hline $5-(07 / 12 / 01)$ & - & 3.39 & 7.1 & 0.5 & 1.0 & 0.045 & 28.8 & 22.04 & -2.34 & 770 & 6500 \\
\hline $6-(07 / 16 / 01)$ & 3.0 & 1.82 & 7.2 & 0.4 & 1.0 & 0.05 & 32.0 & 22.68 & -2.22 & 705 & 680 \\
\hline $7-(07 / 19 / 01)$ & 1.0 & 2.31 & 7.7 & 0.5 & 1.0 & 0.067 & 42.88 & 21.12 & -1.676 & 315 & 270 \\
\hline $8-(07 / 23 / 01)$ & 3.0 & 2.29 & 7.2 & 0.4 & 2.0 & 0.062 & 39.68 & 20.22 & -2.102 & 460 & 900 \\
\hline $9-(07 / 26 / 01)$ & 3.0 & 3.41 & 7.3 & 0.4 & 1.0 & 0.047 & 30.08 & 21.0 & -2.051 & 310 & 440 \\
\hline $10-(07 / 30 / 01)$ & 1.0 & 2.8 & 7.5 & 0.5 & 1.0 & 0.063 & 40.32 & 24.84 & -1.875 & 215 & 990 \\
\hline Average & 2.67 & 2.83 & 7.33 & 0.52 & 1.10 & 0.06 & 37.70 & 22.93 & -1.95 & 497 & 2438 \\
\hline Standard Deviation & 1.51 & 0.68 & 0.23 & 0.18 & 0.32 & 0.01 & 6.33 & 2.14 & 0.30 & 345 & 2812 \\
\hline Variation Coef. (\%) & 56.46 & 24.18 & 3.09 & 33.68 & 28.75 & 16.80 & 16.79 & 9.32 & 15.57 & 69.46 & 115.36 \\
\hline Clogging risk $^{1}$ & B & $\mathrm{S} / \mathrm{C}$ & M & M & M & $\mathrm{S} / \mathrm{C}$ & B & $\mathrm{S} / \mathrm{C}$ & $\mathrm{S} / \mathrm{C}$ & $\mathrm{S} / \mathrm{C}$ & B \\
\hline
\end{tabular}

${ }^{1}$ clogging risk offered to the drippers, according to Bucks \& Nakayama (1986):

B - low risk, $M$ - medium, A - high risk and S/C - no classification.

Sci. Agric. (Piracicaba, Braz.), v.61, n.2, p.127-133, Mar./Apr. 2004 
Table 2 - Physical and biological quality parameters of the water- measured after filtering, during the period June $29^{\text {th }}$ to July $30^{\text {th }} 2001$.

\begin{tabular}{|c|c|c|c|c|c|c|c|c|}
\hline \multirow{4}{*}{$\begin{array}{l}\text { Essay number } \\
\text { and date }\end{array}$} & \multicolumn{8}{|c|}{ Filter effluent parameters } \\
\hline & \multicolumn{4}{|c|}{ Physical } & \multicolumn{4}{|c|}{ Biological } \\
\hline & \multicolumn{2}{|c|}{ Suspended solids } & \multicolumn{2}{|c|}{ Turbidity } & \multicolumn{2}{|c|}{ Algae } & \multicolumn{2}{|c|}{ Bacteria } \\
\hline & Woven Filter & Disc Filter & Woven Filter & Disc Filter & Woven Filter & Disc Filter & Woven Filter & Filter Disc \\
\hline $1-(06 / 29 / 01)$ & 5 & 5 & 2.9 & 3.18 & 125 & 110 & 17 & 10 \\
\hline $2-(07 / 02 / 01)$ & - & - & 2.77 & 3.13 & 240 & 160 & 1300 & 3800 \\
\hline $3-(07 / 05 / 01)$ & - & - & 5.37 & 3.71 & 380 & 305 & 1000 & 1300 \\
\hline $4-(07 / 10 / 01)$ & - & - & 2.8 & 3.28 & 365 & 370 & 6500 & 5900 \\
\hline $5-(07 / 12 / 01)$ & - & - & 3.26 & 2.86 & 335 & 250 & 1000 & 800 \\
\hline $6-(07 / 16 / 01)$ & 2 & 5 & 1.65 & 1.84 & 340 & 460 & 340 & 1400 \\
\hline $7-(07 / 19 / 01)$ & 5 & 2 & 1.79 & 1.99 & 180 & 290 & 440 & 610 \\
\hline $8-(07 / 23 / 01)$ & 3 & 3 & 2.18 & 2.36 & 190 & 250 & 1100 & 1400 \\
\hline $9-(07 / 26 / 01)$ & 2 & 2 & 2.98 & 3.48 & 190 & 225 & 470 & 620 \\
\hline $10-(07 / 30 / 01)$ & 2 & 2 & 2.44 & 2.42 & 105 & 205 & 740 & 840 \\
\hline Average & 1.90 & 1.90 & 2.81 & 2.83 & 245.00 & 262.50 & 1290.70 & 1668.00 \\
\hline Standard Dev. & 1.97 & 1.97 & 1.04 & 0.64 & 102 & 101 & 1873 & 1799 \\
\hline Variation Coeff. (\%) & 103.64 & 103.64 & 36.92 & 22.66 & 41.72 & 38.50 & 145.11 & 107.88 \\
\hline
\end{tabular}

Among biological factors that may cause dripper cloggings, concentrations of algae and bacteria in the reservatory were analysed (Table 1 ). Concentration of algae averaged 497 algae $\mathrm{mL}^{-1}$, with $\mathrm{SD}$ of 345 algae $\mathrm{mL}^{-1}$ and $\mathrm{CV}$ of $69.46 \%$. The highest algae concentration was 1295 algae $\mathrm{m} \mathrm{L}^{-1}$ (Essay 3) and the lowest was 165 algae $\mathrm{m} \mathrm{L}^{-1}$ (Essay 1). This dynamic behavior in algae population may represent risk to the irrigation system when efficient irrigation water treatment is not performed. On the other hand, this variability also indicates the great sensitivity of the organisms in relation to water quality.

Concentration of bacteria also presented large variation. The medium concentration during the whole period was 2438 bacteria $\mathrm{mL}^{-1}, \mathrm{SD}=2812$ bacteria $\mathrm{mL}^{-1}$; $\mathrm{CV}=115.36 \%$; through was 440 bacteria $\mathrm{mL}^{-1}$ (Essay 9), and peek was 6500 bacteria $\mathrm{mL}^{-1}$ (Essays 3, 4 and 5). When abrupt changings occur in the values of biological water parameters, usually resulting from environmental factors, the filtering efficiency of trickle irrigation systems can be affected and equipment has to be turned off until the suspended solids present in the water are reduced to an adequate level (Nakayama \& Bucks, 1991). Bacteria concentration increases followed algae population increases inside the reservatory (Figure 2).

Suspended solids concentration varied between 1 $\mathrm{mg} \mathrm{L}^{-1}$ (Essays 7, 10) and $5 \mathrm{mg} \mathrm{L}^{-1}$, with an average of $2.67 \mathrm{mg} \mathrm{L}^{-1}, \mathrm{CV}=56.46 \%$. This indicates that the suspended solid concentration was found at low clogging risk levels according to the classification proposed by Bucks \& Nakayama (1986). This average is extremely low for a reservatory used as a supplying source, with no flow- ing water. Certainly there is suspended material sedimentation in the water.

Water turbidity varied from 1.82 to 3.88 NTU, average $2.83 \mathrm{NTU}, \mathrm{SD}=0.68 \mathrm{NTU}$, and $\mathrm{CV}=22.18 \%$. Since the suspended solid concentration and turbidity were also low, the water was considered of good quality for trickle irrigation, within the study period. The turbidity is an indication of the presence of suspended solids, but alone it is not a precise parameter to define the risk of dripper clogging when using superficial water sources (Pitts et al., 1990). Turbidity should be anlysed through laboratory filtering tests, specific for measuring clogging risk potential (Gilbert \& Ford, 1986).

The data collection period (Table 1) corresponded to drought and low pluvial precipitations (winter). The $\mathrm{pH}$ varied from 7.1 to 7.7 (average 7.33 ), $\mathrm{SD}=0.21$ and $\mathrm{CV}=3.09 \%$. According to the classification proposed by Bucks \& Nakayama (1986), these values represent me-

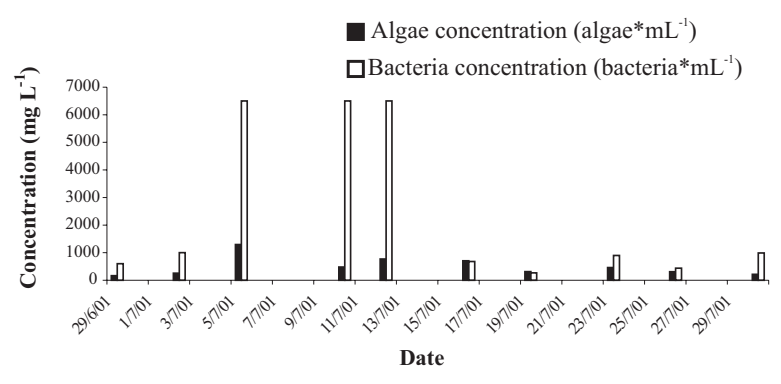

Figure 2 - Algae and bacteria concentration in the reservatory water.

Sci. Agric. (Piracicaba, Braz.), v.61, n.2, p.127-133, Mar./Apr. 2004 
dium clogging risk. High $\mathrm{pH}$ (above 8.0) may cause precipitation of salts, manly calcium carbonate. The ideal $\mathrm{pH}$ for trickle irrigation water lies around 6.5. The electric conductivity (EC) varied from 0.045 to $0.076 \mathrm{mS} \mathrm{cm}^{-1}$, $\mathrm{SD}=0.01 \mathrm{mS} \mathrm{cm}^{-1}$ and $\mathrm{CV}=16 \%$, an indication that dissolved solid concentration was 28.8 to $48.64 \mathrm{mg} \mathrm{L}^{-1}$, $37.70 \mathrm{mg} \mathrm{L}^{-1}$ in average, $\mathrm{SD}=6.33 \mathrm{mg} \mathrm{L}^{-1}$ and $\mathrm{CV}=$ $16.79 \%$. very low values, according to the classification of Bucks \& Nakayama (1986). Concentrations of dissolved solids below $500 \mathrm{mg} \mathrm{L}^{-1}$ are considered of low risk to trickle irrigation systems.

Water hardness varied from 21.0 to $26.63 \mathrm{mg} \mathrm{L}^{-1}$, $22.93 \mathrm{mg} \mathrm{L}^{-1}$ in average, $\mathrm{SD}=2.14 \mathrm{mg} \mathrm{L}^{-1}$ and $\mathrm{CV}=$ $9.32 \%$. According to the water classification of the U.S. Geological Survey, these values classify the water as Class 1, indicating a low hardness degree. According to Todd (1980) this water presents a low clogging potential in relation to $\mathrm{CaCO}_{3}$ precipitation. This can be confirmed through the Langelier index that varied from -2.22 to $1.399,-1.95$ in average, $\mathrm{SD}=0.30$ and $\mathrm{CV}=15.57 \%$.

Sulphite and iron concentrations are presented in Figure 3. There was a variation from 0.4 to $1 \mathrm{mg} \mathrm{L}^{-1}$ for iron, $0.52 \mathrm{mg} \mathrm{L}^{-1}$ in average, $\mathrm{SD}=0.18 \mathrm{mg} \mathrm{L}^{-1}$ and $\mathrm{CV}=$ $33.68 \%$. Sulphite values varied from 1.0 to $2.0 \mathrm{mg} \mathrm{L}^{-1}$, $1.10 \mathrm{mg} \mathrm{L}^{-1}$ in average, $\mathrm{SD}=0.32 \mathrm{mg} \mathrm{L}^{-1}$ and $\mathrm{CV}=$ $28.75 \%$. According to Bucks \& Nakayama (1986), these values indicate medium clogging risk. The $0.5 \mathrm{mg} \mathrm{L}^{-1} \mathrm{Fe}$ concentration must be considered as maximum permitted; however, when considering the cost of filters, the maximum practical value is $2 \mathrm{mg} \mathrm{L}^{-1}$ (Ayres \& Westcot, 1991).

Some iron-bacteria interaction problems have been observed in $0.1 \mathrm{mg} \mathrm{L}^{-1}$ iron concentration (English, 1985). Concentrations of iron above $0.2 \mathrm{mg} \mathrm{L}^{-1}$ are considered a significant clogging risk. Precipitated iron forms red incrustations, that may adhere to the PVC of pipe walls and may also clog emitters. Some filamentous bacteria, e.g. Gallionella and Leptotrhix, oxydate $\mathrm{Fe}^{+2}$ to $\mathrm{Fe}^{+3}$ which may precipitate and cause clogging (Pizarro, 1996). Water used in trickle irrigation systems with iron concentrations above $0.4 \mathrm{mg} \mathrm{L}^{-1}$ contributes to the development of filamentous, ferric bacteria, which cause emitter obstruction (Ford \& Tucker, 1986).

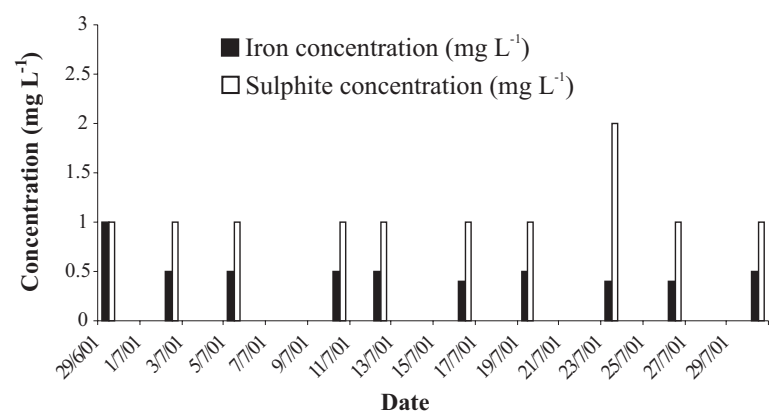

Figure 3 - Sulphite and iron concentration in the reservatory.
Manganese concentrations in all water samples were so low that could not be detected by the equipment. Table 2 shows water data deriving from sampling points after the filters. Water turbidity after the filtering elements was very similar for both filtering systems. On the sixth and seventh essays, there was a small reduction in water turbidity. The turbidity average for both filters was very similar: $2.81 \mathrm{NTU}, \mathrm{SD}=1.04 \mathrm{NTU}$ and $\mathrm{CV}=36.92 \%$ for the non-woven, synthetic fabric filter. For the disc filter these values were 2.83 NTU, 0.64 NTU and $22.66 \%$, respectively.

The average values for suspended solids of the samples from the two filtering systems were $1.90 \mathrm{mg} \mathrm{L}^{-1}$ in average, with a $1.97 \mathrm{mg} \mathrm{L}^{-1}$ standard deviation and a coefficient of variation of $103.64 \%$. The medium algae concentration $245 \mathrm{~m} \mathrm{~L}^{-1}$, with a 102 algae $\mathrm{m} \mathrm{L}^{-1}$ standard deviation and a $41.72 \%$ coefficient of variation for the non woven synthetic fabric filter, and 263 algae $\mathrm{m} \mathrm{L}^{-1}$, with a standard deviation of 101 algae $\mathrm{m} \mathrm{L}^{-1}$ and a coefficient of variation of $38.50 \%$ for the disc filter.

Although the non-woven, synthetic fabric filter is used in pressurized system for fast filtering, the mechanisms involved in the algae retention may be linked to impurity adherence by the fiber net, resulting in the formation of a biological layer. The diameters of the nonwoven, syntethic fabric filter fibers are between 2 and 100 $\mathrm{mm}$ and, therefore, appropriated for the removal of particles present in the water, between 1 and $100 \mathrm{~mm}$ (Wilkinson, 1986).

The average bacterial population was $1291 \mathrm{bac}-$ teria $\mathrm{mL}^{-1}, \mathrm{SD}=1873$ bacteria $\mathrm{mL}^{-1}$ and $\mathrm{CV}=145.11 \%$ for the non-woven, synthetic fabric filter, and 1668 bacteria $\mathrm{mL}^{-1}, 1799$ bacteria $\mathrm{mL}^{-1}$ and $107.88 \%$, respectively, for the filter disc. Average physical parameters (suspended solids and turbidity) found for both filters were very close. For suspended solids the averages were the same $1.90 \mathrm{mg} \mathrm{L}^{-1}$ and turbidity of $2.81 \mathrm{NTU}$ to the nonwoven, synthetic fabric filter and 2.83 NTU to the disc filter. The high values of the CVs obtained for the biological parameters, mainly regarding bacteria, demonstrate the high sensitivity of these parameters considering the environmental variation during the short experimentation period. The non-woven, synthetic fabric filter tends to be more efficient than the disc filter, considering the removal of suspended solids, algae and bacteria (Ribeiro et al., 2002). This explains why the head loss average in function of the filtered volume is more intense for the non-woven, synthetic fabric filter than for the disc filter. Scatolini (2001) has also found that the non-woven, synthetic fabric filter was more efficient than the 130 micron screen filter, for the removal of suspended solids and algae.

The head loss increased continuously until the moment of a slump, followed by another period of increase, and so on (Figure 4). The most abrupt slumps, in which the head loss returns to values under $20 \mathrm{kPa}$, rep-

Sci. Agric. (Piracicaba, Braz.), v.61, n.2, p.127-133, Mar./Apr. 2004 
resent moments when the filtering elements were being washed, while the less intense slumps represent only the transition between irrigation shifts. However, during the first assays, the non-woven, synthetic fabric filters presented head losses above $100 \mathrm{kPa}$ and $80 \mathrm{kPa}$. The cleaning of the filtering material was attempted, as soon as pressure differential hit $40 \mathrm{kPa}$, turning necessary to proceed the cleaning of the disc filter. Faster increases in head loss in the non-woven, synthetic fabric results from higher suspended solids retention, that obstructs partially the filtering (Scatolini, 2001).

Depending on the efficacy of the algae and bacteria removal, the mechanisms involved in algae retention may be linked to impurity adherence to the fiber net, resulting in the formation of a biological layer, and as a consequence, a higher head loss. The non-woven, synthetic fabric filter, was more efficient in the removal of biological material, resulting in a more frequent cleaning of the filtering element. A more tenuous head loss in the nonwoven, synthetic fabric filter, indicates that this filter has a better effective filtering area than the disc filter in relation to the filtered volume. During the experimental period, 21 cleanings were performed in the non-woven, synthetic fabric filter, while no cleaning procedure was needed for the disc filter, (head loss stipulated as $40 \mathrm{kPa}$ ).

When the water quality became worse due to increasing in the amount of impurities, the backwashing was reduced, and the head loss increased quickly to the same filtered volume. Nakayama \& Bucks (1991) reported that, when high concentration of suspended materials was present in the irrigation water, a more frequent cleaning of the trickle irrigation elements was need, and suggested that for better control of the removal of the suspended particles, it would be advisable to have automatic backwash of the filter.

The disc filter head loss did not vary significantly during the period. It was always near $10 \mathrm{kPa}$ because, according to the analysis of the quality of the water of the reservatory, it presented a low clogging potential, with low concentration of suspended solids.

A comparative analysis was performed on the head loss evolution from the non-woven, synthetic fabric filter before and after utilization checking for possible deterioration and modification of characteristics (Figure 5 ). When the head loss reaches $40 \mathrm{kPa}$ there is a faster increase in head loss evolution as compared to the material after some cleaning procedures (average curve). These effects result from the cleaning procedures, and indicate that their characteristics, mainly regarding the diameter of pore openings, may have been modified due to the usage of high pressure water jets during the cleaning procedures. Another hypothesis regarding the deformation of the filtering material is related to the pressure of the irrigation system, indicating the need of a stronger filter structure to work as support for the filters.

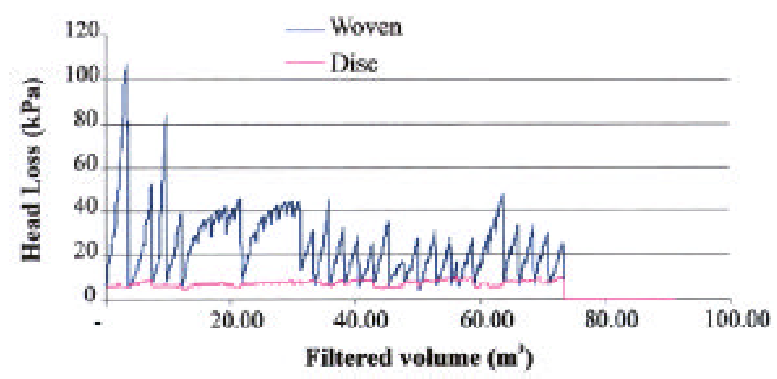

Figure 4 - Head loss variation versus filtered volume of disc and non woven synthetic fabric filters.

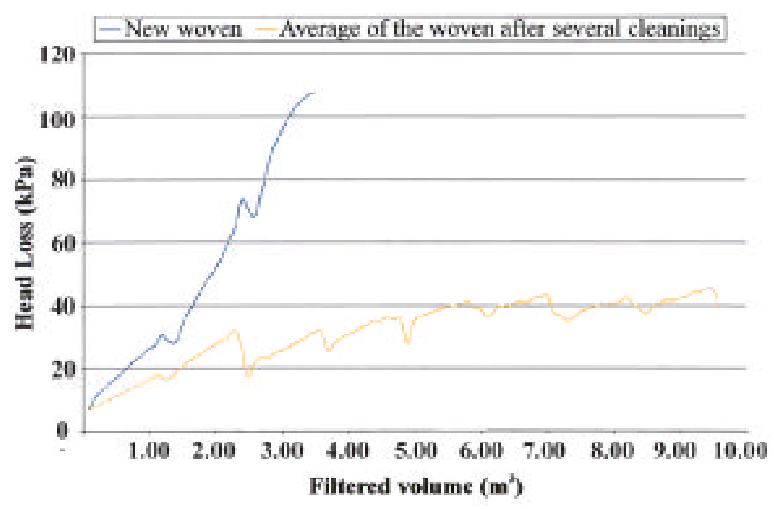

Figure 5 - Head loss curve with a new non woven synthetic fabric filter and average curve (after all the cleanings proceeded during the field essays).

A pressure differential control should be adapted to make an automatic backwashing of the non-woven, synthetic fabric filter, enabling better practicity during its maintenance. Besides, assays with other kinds of nonwoven, synthetic fabric filters should be accomplished, finding fabrics that present better efficiency of impurity removal with lower head loss, considering the filtered volume. Future studies with different kinds of fabrics, thicknesses and filtering areas, may indicate which are the best characteristics of these elements for tricke irrigation.

\section{ACKNOWLEDGMENTS}

To FAPESP, for finantial support (Project 00/ 01292-5) and scholarships (01/02059-9 and 01/01719-1).

\section{REFERENCES}

ADIN, A.; ALON, G. Mechanisms and process parameters of filter screens. Journal of Irrigation and Drainage Engineering, v.112, p.293-304, 1986.

AYRES, R.S.; WESTCOT, D.W. A qualidade da água na agricultura. Campina Grande: UFPB, 1991. 218p.

AMERICAN PUBLIC HEALTH ASSOCIANTION; AMERICAN WATER WORKS ASSOCIATION; WATER POLLUTION CONTROL FEDERATION. Standard methods for the examination of water and wastewater. 16.ed. Washington: APHA, 1985. 1268p 
BUCKS, D.A.; NAKAYAMA, F.S. Trickle irrigation for crop production Design, operation and management. Amsterdam: Elsevier, 1986. 383p.

ENGLISH, S.D. Filtration and water treatment for micro-irrigation. In: INTERNACIONAL DRIP/TRICKLE IRRIGATION CONGRESS, 3. Fresno, 1985. Proceedings. St. Joseph: ASAE, 1985. p.50-57.

FORD, H.A.; TUCKER, D.P.H. Clogging of drip systems from metabolic products of iron and sulfur bacteria. In: INTERNATIONAL DRIP IRRIGATION CONGRESS, 2., San Diego, 1986.

GILBERT, R.G.; FORD, H.W. Operational principles/emitter clogging. In NAKAYAMA, F.S.; BUCKS, D.A. Trickle irrigation for crop production: Design, operation and management. Amsterdam: Elsevier, 1986. cap.3, p.142-163.

LOPEZ, J.R.; HERNANDEZ, J.M.A.; REGALADO, A.P.; HERNANDEZ J.F.G. Riego localizado. 1.ed. Regadios: Centro Nacional de Tecnologia de Regadios, Ministerio de Agricutura, Pesca y Alimentacion, IRYDA, 1992. 445p.

NAKAYAMA, F.S.; BUCKS, D.A.; FRENCH, O.F. Reclaiming partially clogged trickle emitters. Transactions of the ASAE, v.20, 278-280, 1977.

NAKAYAMA, F.S.; BUCKS, D.A. Water quality in drip/trickle irrigation: a review. Irrigation Science, v.12, p.187-192, 1991.

NAKAYAMA, F.S.; BUCKS, D.A. Temperature effect on calcium carbonate precipitate clogging of trickle emitters. In: INTERNATIONAL DRIP/ TRICKLE IRRIGATION CONGRESS, 3., Fresno, 1985. Proceedings. St. Joseph: ASAE, 1985. p.45-49.

PATERNIANI, J.E.S. Utilização de mantas sintéticas não tecidas na filtração lenta em areia de águas de abastecimento. São Carlos: USP/EESC, 1991. 245p. (Tese - Doutorado).

PATERNIANI, J.E.S.; SILVA, L.B. Comparação entre diferentes meios filtrantes de filtros para irrigação localizada. In: CONGRESO ARGENTINO DE INGENIERIA RURAL, 4.; CONGRESSO INTERNACIONAL DE INGENIERIA RURAL, 2., Neuquen, 1996. Memorias. Neuquen: Univesidad Nacional Del Comahue, 1996. p.397401 .
PITTS, D.J.; HAMAN, D.Z; SMAJSTLA, A.G. Causes and prevention of emitter plugging in microirrigation systems. Gainesville: Florida Cooperative Extension Service, University of Florida, 1990. (Bulletin 258).

PIZARRO, F. Riegos localizados de alta frequência. 3.ed. Madrid: Mund Prensa, 1996. 513p.

RIBEIRO, T.A.P.; PATERNIANI, J.S.; AIROLDI, R.P.S.; SILVA M.J.M. Avaliação do desempenho dos filtros de discos e manta sitética não tecida utilizados para irrigação por gotejamento quando se utiliza fertirrigação. In: CONGRESSO BRASILEIRO DE ENGENHARIA AGRÍCOLA, 31. Salvador, 2002. Máquinas e mecanização agrícola; anais. Salvador, 2002. CRRom

SCATOLINI, M.E. Utilização de mantas não tecidas como elemento filtrante em sistemas de irrigação localizada. Campinas: UNICAMP/FEA, 2001. (Tese - Doutorado).

SILVA, L.B. Utilização de mantas sintéticas não tecidas na filtração sob pressão. Campinas: UNICAMP/FEA, 1996. (Dissertação - Mestrado).

TODD, D.K. Groundwater hydrology. New York: John Wiley and Sons, 1980. 282p.

WILKINSON, F.S. The filtration of Dilute Suspensions using non-woven cloths and membranes. In: WORLD FILTRATION CONGRESS, 4. Ostend, 1986. Proceeding. Antwerpen: Royal Flemish Society of Engineers, 1986.

Received August 26, 2002 Accepted January 28, 2004

Sci. Agric. (Piracicaba, Braz.), v.61, n.2, p.127-133, Mar./Apr. 2004 